\title{
SUPERNUMERARY TOOTH IN THE PRIMARY MOLAR REGION: CASE REPORT
}

\author{
Mi-Seon Park, Ho-Won Park, Ju-Hyun Lee, Hyun-Woo Seo \\ Department of Pediatric Dentistry, Oral Science Research Center, School of Dentistry, Gangneung-wonju National University
}

\begin{abstract}
Supernumerary teeth are dental abnormalies in the permanent dentition and the primary dentition. The etiology is unclear, but it may occur due to dichotomy of the tooth bud or hyperactivity of dental lamina. They occur more in the permanent dentition than in the primary dentition, with the most common site being the premaxillary area. Supernumerary teeth can be classified by morphology and position. Supplemental tooth refers to normal shape tooth. The treatment of supernumerary teeth depends on its shape, position, effect on dentition, and child's physiological condition. In this case, supernumerary primary tooth in the maxillary molar area was revealed by radiographical and clinical examination, but it was difficult to determine which is the supernumerary tooth. The tooth on the mesial side was extracted to induce the formation of adequate space and to prevent excessive space loss, and the result was favorable.
\end{abstract}

Key words : Supernumerary primary tooth, Supplemental tooth, Tooth drifting

\section{Introduction}

Supernumerary teeth are extra teeth in the normal dentition. The etiology of supernumerary teeth is not completely understood. However several theories have been suggested for their occurrence. The localized and independent hyperactivity of the dental lamina are the most common accepted causes for the development of supernumerary teeth ${ }^{1,2)}$.

They can occur in any region in the dental arch, but the most common region is the premaxilla. They occur less frequently in primary dentition than in permanent dentition $^{1.3)}$. It is overlooked because they are often normal shape, erupt normally and appear to be in proper alignment ${ }^{4)}$.

Classification of supernumerary teeth is based on their location or morphology. Based on the morphology, (1) conical : peg shape teeth, (2) tuberculate : made of more than one cusp or tubercle. They are barrel shaped and are usually invaginated, and (3) supplemental : resemble normal teeth" .

The supernumerary teeth can cause several complications; Failure of eruption, displacement, crowding, root resorption of adjacent teeth, cystic formation ${ }^{6.7}$. Therefore early diagnosis and treatment of supernumerary teeth are important.

The aim of this paper is to report a case of supernumerary primary teeth in the maxillary molar region.

\section{Case report}

A 4year-3month-old girl presented to the Department of Pediatric Dentistry, Gangnung-wonju University School of Dentistry with a chief complaint of dental caries. She was anxious during previous dental treatment. She had no remarkable medical history and famil-

\section{교신저자 : 서 현 우}

강원도 강릉시 강릉대학로 120 / 강릉원주대학교 치과대학 소아치과학교실 / 033-640-2758 / hwseo@kangnung.ac.kr

원고접수일: 2010년 09월 17일 / 원고최종수정일: 2010년 11월 25일 / 원고채택일: 2010년 12월 02일 
ial history.

Clinical and radiographic examination revealed (1) mandibular left primary lateral incisor was congenital missing and (2) supernumerary tooth in the region of the maxillary left molar area.

It was difficult to determine which is the supernumerary tooth. We named the tooth of mesial side as E1 and the tooth of distal side as E2(Fig. 1). E1 was seemed to have identical morphology as the maxillary primary second molar(Fig. 1). There were no other complications, but E1 made excess space in the dental arch to make it questionable that appropriate eruption of the permanent left maxillary first and second molar is possible or not. We made treatment plan. The treatment plan involves monitoring of developmental state of the permanent left maxillary first molar. Extraction of supernumerary tooth was scheduled after evaluation of the left maxillary permanent first molar.

For the root formation of the left maxillary permanent first molar, E1 tooth was extracted to reduce space on the left side in the dental arch and to promote eruption of the left maxillary permanent molars.

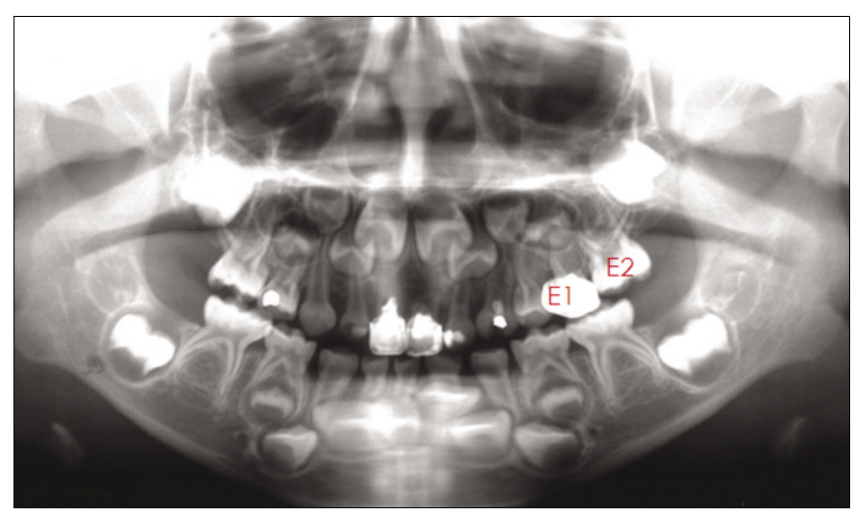

Fig. 1. Panoramic radiograph at first visit.

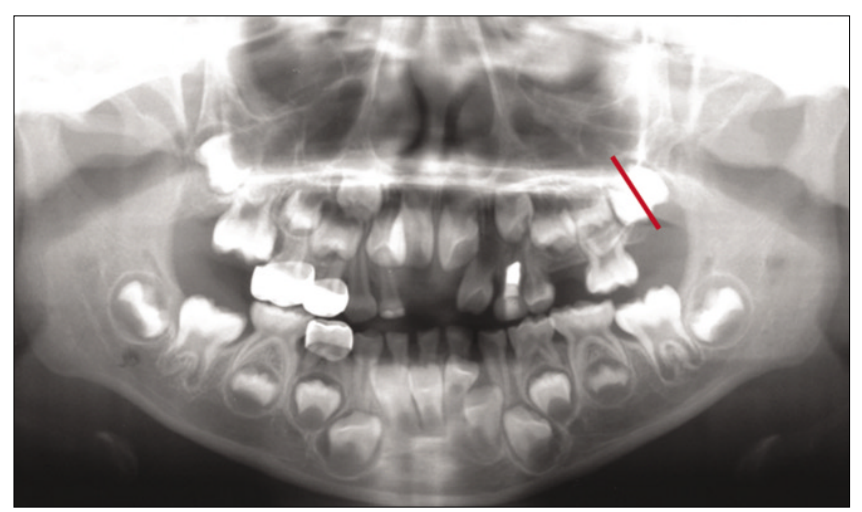

Fig. 2. Panoramic radiograph 12 months after extraction of E1.
E2 and maxillary left first molar showed progressive bodily movement to mesial side after extraction of $\mathrm{E} 1$ tooth(Figs. 2-5). Eruption of left maxillary first molar was satisfactory, in addition favorable eruption of left maxillary second molar is being expected(Fig. 5). Furthermore, selective grinding of $\mathrm{E} 2$ tooth is needed for Class I molar key in the left side.

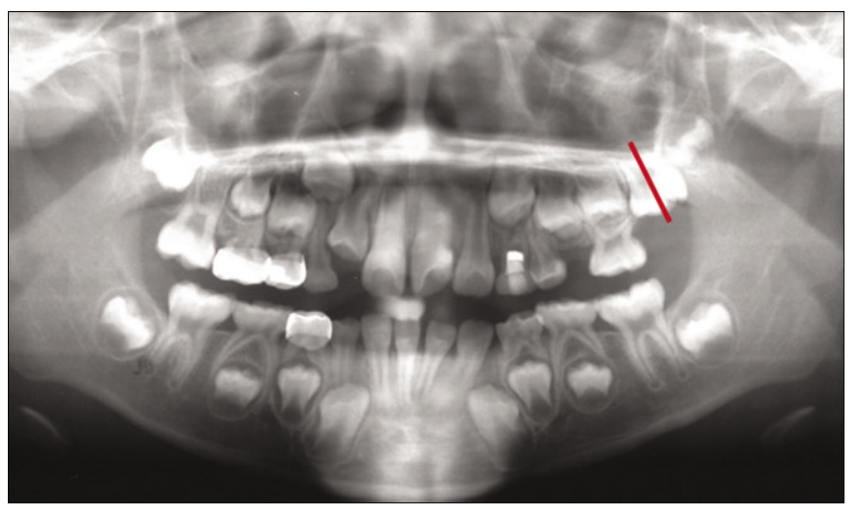

Fig. 3. Panoramic radiograph 33 months after extraction of E1.

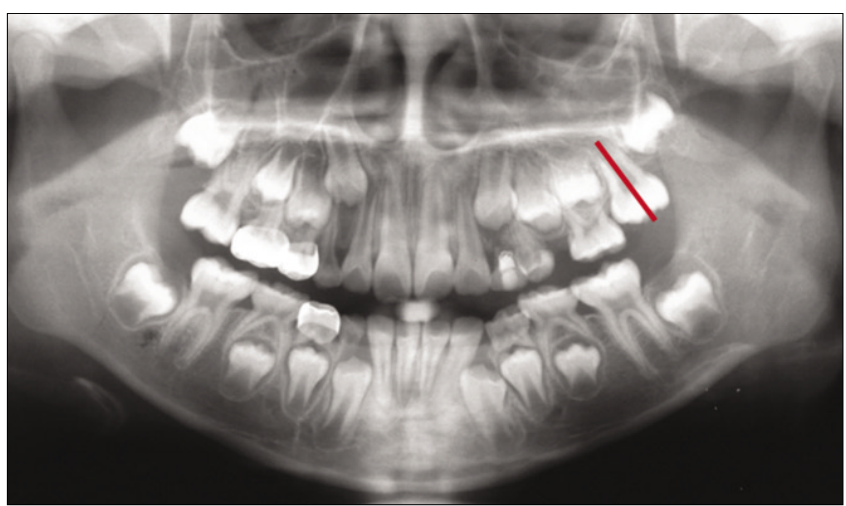

Fig. 4. Panoramic radiograph 46 months after extraction of E1.

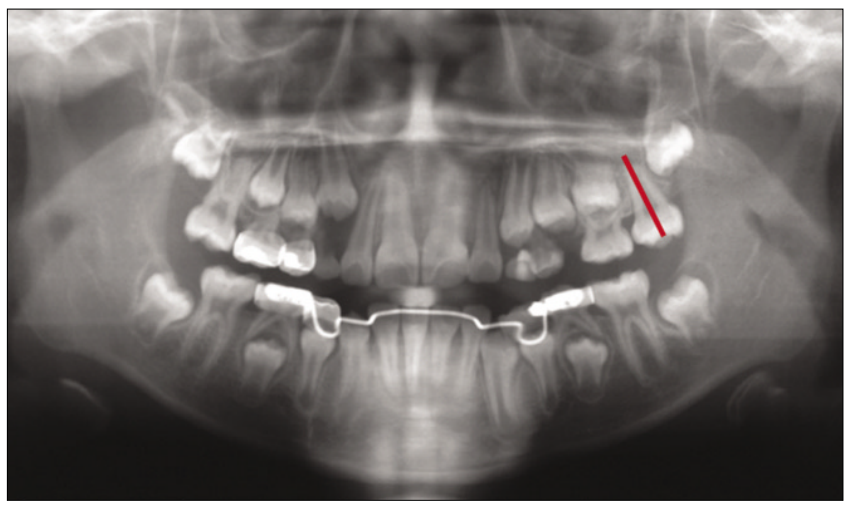

Fig. 5. Panoramic radiograph 58 months after extraction of E1. 


\section{Discussion}

The majority of supernumerary teeth found in the primary dentition are supplemental type and rarely remain unerupted $^{8}$. Previous studies confirm that supernumerary primary teeth in the molar region, especially in proper alignment within the dental arch, as reported here, are extremely rare. But these cases are extremely rare.

Whittington and Durward ${ }^{9)}$ have suggested that supplemental maxillary lateral incisor is the most commonly occuring supernumerary tooth in the primary dentition. Miyoshi et al ${ }^{10)}$ examined 8,122 3-to 4-year-old Japanese children for supernumerary primary teeth and reported that all of the supernumerary primary teeth found were located in the maxillary lateral incisor area. On the other hand, only two cases of supernumerary primary tooth in molar area were reported by Trenouth and Bedi ${ }^{11}$, Shimizu et $\mathrm{al}^{12}$.

Extraction is not always the treatment of choice for supernumerary teeth ${ }^{13)}$. Treatment of supernumerary teeth case will depend on: its type, location, effect on dentition and child's physiological condition ${ }^{5)}$. Removal of the supernumerary teeth right after it has been diagnosed, cause dental phobia problems for a young child ${ }^{14)}$. In this case, the supernumerary primary tooth showed no pathologic change, so kept under observation. No treatment of supernumerary teeth was planned, but it was monitored radiographically. The parent should be informed of possible complications.

If supplemental tooth is erupted, it may be difficult to determine which is the supplemental and which is the tooth of the normal dental series ${ }^{15}$. In these situation, it is reasonable to extract the most displaced tooth from the line of the arch for the relief of crowding ${ }^{16}$. In this present case, E1 was extracted. The reason of extraction of $\mathrm{E} 1$ is as follows. If $\mathrm{E} 2$ was extracted, maxillary left first molar would be tilted mesially, leading to becoming barrier of left maxillary second premolar eruption. Futhermore E2 was intact in contrast to E1 which had to be treated with stainless steel crown.

The spontaneous movements made by teeth following the extraction of neighboring teeth ${ }^{17)}$ : (1) extrusion of opposing teeth, (2) drifting or (3) tipping of adjacent teeth. The difference of tooth movement between the maxillary and mandibular teeth was reported by Kisling and Høffding ${ }^{18}$. The movement of the maxillary first molar is mesial drift combined with a rotation around the palatal root, whereas tipping is seldom. On the other hand mandibular first molar will tip mesially with lingual movement. In this case, maxillary first molar showed drifting after extraction of supernumerary tooth, and it provided adequate space for permanent teeth.

\section{Summary}

In this case supernumerary tooth was extracted, because it induced excessive space for permanent teeth. The patient has been followed-up for 6 years. It has been found that bodily movement of maxillary left first molar occurred to mesial side after extraction of E1. It needs follow-up until succedaneous permanent teeth eruption.

\section{References}

1. Taylor GS : Characteristics of supernumerary teeth in the primary and permanent dentitions. Dent Pract Dent Rec, 22:203-208, 1972.

2. Levine $N$ : The clinical management of supernumerary teeth. J Can Dent Assoc, 28:297-303, 1961.

3. Brook AH : Dental anomalies in number, form and size: their prevalence in Brithsh schoolchildren. J Int Assoc Dent Child, 5:37-53, 1974.

4. Humerfelt D, Hurlen B, Humerfelt S : Hyperdontia in children below four years of age: a radiographic study. ASDC J Dent Child, 52:121-124, 1985.

5. Garvey MT, Barry HJ, Blake M : Supernumerary teeth-An overview of classification, diagnosis and management. J Can Dent Assoc, 11:612-616, 1999.

6. Hogstrum A, Andersson L : Complications related to surgical removal of anterior supernumerary teeth in children. J Dent Child, 54:341-343, 1987.

7. Nae-Jeon Jeong, Chong-Chul Kim, Sang-Hoon Lee : A case bilateral supernumerary teeth in the mandibular incisor region: A case report. J Korean Acad Pediatr Dent, 1:17-25, 2001.

8. Garvey MT, Barry HJ, Blake M : Supernumerary teeth-An overview of classification, diagnosis and management. J Can Dent Assoc, 11:612-616, 1999.

9. Whittington BR, Durward CS : Survey of anomalies in primary teeth and their correlation with the permanent dentition. N Z Dent J. 92:4-8, 1996.

10. Miyoshi S, Tanaka S, Kunimatsu H : An epidemiological study of supernumerary primary teeth in Japanese children: a review of racial differences in 
the prevalence. Oral dis, 6:99-102, 2000.

11. Trenouth MJ, Bedi R : Supernumerary primary first molar and first premolar: clinical report. Pediatr Dent, 5:214-216, 1983.

12. Shimizu T, Miyamoto M, Arai Y, Maeda T : Supernumeary tooth in the primary molar region: A case report. J Dent Child, 74:151-153, 2007.

13. Rajab LD, Hamdan MA : Supernumeary teeth: review of the literature and a survey of 152 cases. Int J Paediatr Dent, 12:244-254, 2002.

14. Hogstrum A, Andersson L : Complications related to surgical removal of anterior supernumerary teeth in children. J Dent Child, 54:341-343, 1987.

15. Min-Hyung Oh, Kwang-Hee Lee, Dae-Eup Kim, Ji-
Young Ra : Case report: Supernumerary teeth on maxillary premolar and mandibular incisal area. J Korean Acad Pediatr Dent, 3:529-533, 2006.

16. Shah A, Gill DS, Tredwin C, Naini FB : Diagnosis and management of supernumerary teeth. Dent Update, 35:510-520, 2008.

17. Kaplan P : Drifting, tipping, supraeruption, and segmental alveolar bone growth. J Prosthet Dent, 54:280-283, 1985.

18. Kisling E, Høffding $J$ : Premature loss of primary teeth: part III, drifting patterns for different types of teeth after loss of adjoining teeth. ASDC J Dent Child, 46:34-38, 1979. 


\title{
상악 유구치부에 발생한 과잉치의 치험례
}

\author{
박미선 · 박호원 · 이주현 · 서현우
}

\section{강릉원주대학교 치과대학 소아치과학교실 및 구강과학연구소}

과잉치는 영구치열 및 유치열에서 발생하는 치아 발육 장애이다. 원인은 명확하게 밝혀지지 않았으나 치판의 과도한 활성 으로 인해 발생한다는 이론과 환경적 요인으로 인해 치배가 두 개로 나눠진다는 이론 등이 제시되었다.

과잉치의 발생은 유치열보다는 영구치열에 호발하며 전상악부에 높은 빈도로 발생한다. 과잉치가 발생한 위치나 형태에 따라 분류할 수 있으며 정상적인 형태를 나타날 때 보충치 (supplemental tooth)라고 명명하기도 한다. 과잉치 발생시 치아 의 맹출 장애, 총생, 정중이개, 인접치의 회전이나 흡수, 낭종 등의 합병증을 야기할 수 있으므로 조기 발견 및 진단이 중요하 다. 과잉치의 처치는 형태나 위치, 치열에 미치는 영향 그리고 환아의 심리적 상태 등을 고려하여야 한다. 본 증례에서는 방 사선학적 검사와 임상 검사를 통해 상악의 과잉 유구치를 진단하였다. 하지만 어떤 치아가 과잉치인지 진단하기가 어려웠다. 적절한 공간 형성과 과도한 공간 소실을 방지하기 위하여 악궁의 근심에 위치한 치아를 발거하여 양호한 결과를 얻었다.

주요어: 과잉 유구치, 보충치, 치체 이동 